\author{
Helena Kościelniak* \\ Małgorzata Lęgowik-Małolepsza**
}

\title{
BARIERY W ZARZĄDZANIU INFORMACJĄ W PRZEDSIĘBIORSTWACH PRZEMYSŁU CEMENTOWEGO
}

\section{WSTĘP}

Prowadzenie działalności przedsiębiorstw na rynku kapitałowym stało się obecnie bardzo trudnym zadaniem, przed którym stanęli menedżerowie. Wysoka konkurencja, oszczędni klienci oraz rosnące koszty produkcji skutecznie ograniczają możliwości przedsiębiorców. Efektywne wykorzystywanie szans stwarzanych przez otoczenie wraz z jednoczesną ochroną przed występującymi zagrożeniami jest możliwe poprzez poprawne zarządzanie dostępnymi informacjami. Pokonywanie barier występujących w procesie zarządzania informacją jest możliwe poprzez rozwój wiedzy w przedsiębiorstwie. Zasadniczym celem opracowania jest próba określenia kluczowych obszarów zakłóceń w przepływie informacji przedsiębiorstw przemysłu cementowego. Dla realizacji celu referatu wykorzystano głównie wskaźnik intensywnego wykorzystania maszyn i urządzeń oraz analizę kosztów poniesionych na remont główny w odniesieniu do kosztów poniesionych na usuwanie skutków awarii.

\section{ZARZĄDZANIE INFORMACJĄ JAKO DETERMINANTA ROZWOJU WIEDZY W PRZEDSIĘBIORSTWIE}

Zgodnie z następującym stwierdzeniem, iż ,zarządzanie informacją jest świadomym postępowaniem ludzi, zmierzającym w kierunku optymalizacji roli

\footnotetext{
* Dr hab., Prof. Pcz, Wydział Zarządzania, Politechnika Częstochowska.

*** Mgr, Wydział Zarządzania, Politechnika Częstochowska.
} 
informacji w osiaganiu celów przez organizację"1, podkreśla się wagę informacji. Jednocześnie uznając, iż ,informacja traktowana jest jako jeden z zasadniczych czynników, dzięki którym przedsiębiorstwo może skrócić czas reakcji na zmiany warunków w otoczeniu",2, uznaje się, że głównym zadaniem zarządzania informacją jest rozwój wiedzy w przedsiębiorstwie na rynku kapitałowym.

Dostęp do potrzebnych informacji zwiększa wiedzę przedsiębiorców i wpływa pozytywnie na działalność przedsiębiorstwº ${ }^{3}$. Zarządzanie informacją w przedsiębiorstwie jest silnie związane $\mathrm{z}$ zarządzaniem całą działalnością przedsiębiorstwa. Problemy zarządzania to płaszczyzna, w której zarządzanie informacją ma służyć bieżącemu monitorowaniu zarządzania efektywnością. Ma dostarczać informacji do obliczenia wskaźników efektywności, a w przypadku uzyskania niewłaściwych parametrów tych wskaźników wskazać obszary powodujące te zniekształcenia. Analogicznie do zarządzania efektywnością, zarządzanie informacją ma służyć zarządzaniu jakością. Ma na bieżąco kontrolować poziom jakości we wszystkich możliwych obszarach i uzasadniać przyczyny braków tej jakości, jeśli takie przypadki będą występować ${ }^{4}$.

Wśród problemów w zarządzaniu informacją na pierwszym miejscu wymienić należy bariery związane z dostępnością do źródeł informacji, które prezentuje J. Oleński. Do barier tych zalicza on następujące:

- bariery techniczne - polegają na braku technicznych możliwości dostępu do źródeł informacji,

- bariery prawne - wynikają $\mathrm{z}$ obowiązujących przepisów prawa, a dokładnie z jego ograniczeń; przykładem może być zbyt długi okres oczekiwania na potrzebne informacje, powodujący w konsekwencji nieaktualność uzyskanych informacji,

- bariery organizacyjne - związane z brakiem właściwych organów organizacji zajmujących się pozyskiwaniem, gromadzeniem i analizowaniem informacji,

- bariery ekonomiczne - odnoszą się głównie do barier finansowych, czyli braków środków finansowych niezbędnych do uzyskania dostępu do określonych źródeł informacji,

- bariery psychologiczne - powstają wtedy, kiedy źródłami informacji są ludzie i związane są z indywidualnymi cechami charakteru tych osób, takimi jak: brak pewności siebie, brak chęci do dzielenia się swoimi poglądami i opiniami czy lęk przed ośmieszeniem,

\footnotetext{
${ }^{1}$ R. Zyg ała, Podstawy zarzadzania informacja w przedsiębiorstwie, Wydawnictwo AE we Wrocławiu, Wrocław 2007, s. 46.

${ }^{2} \mathrm{~T}$. Małkus, Usprawnianie procesów informacyjnych $w$ systemie logistycznym przedsiębiorstwa, Zeszyty Naukowe nr 727 AE w Krakowie, Kraków 2007, s. 194.

${ }^{3}$ Zob. A. Puto (red.), Teoretyczne i praktyczne aspekty funkcjonowania przedsiębiorstwa, WZPCz, Częstochowa 2012, s. 141-145.

${ }^{4}$ Zob. P. N o w od zińs ki, Misja wybranych spótek indeksu NewConnect Lead w kontekście ich wyborów strategicznych, ZN UE w Poznaniu nr 171, Poznań 2011, s. 316-326.
} 
- bariery metainformacyjne - dotyczą braku informacji o źródłach informacji i możliwości dostępu do informacji ${ }^{5}$.

Spośród barier sprawnego zarządzania informacją w przedsiębiorstwie L. Kiełtyka i W. Jędrzejczyk wymieniają:

- niekompetencję pracowników,

- nieprawidłowości w funkcjonowaniu systemu informacyjnego przedsiębiorstwa,

- ograniczoną dostępność do źródeł informacji,

- brak wystarczających środków finansowych ${ }^{6}$.

Według M. Mielus (...) przyczyna złego poinformowania poza nadmiarem informacji, przekłamaniami, nieaktualnymi informacjami, niezgodnymi $w$ formie i treści, niesprawdzonymi jest również nieumiejętność jasnego określenia potrzeb informacyjnych ${ }^{7}$.

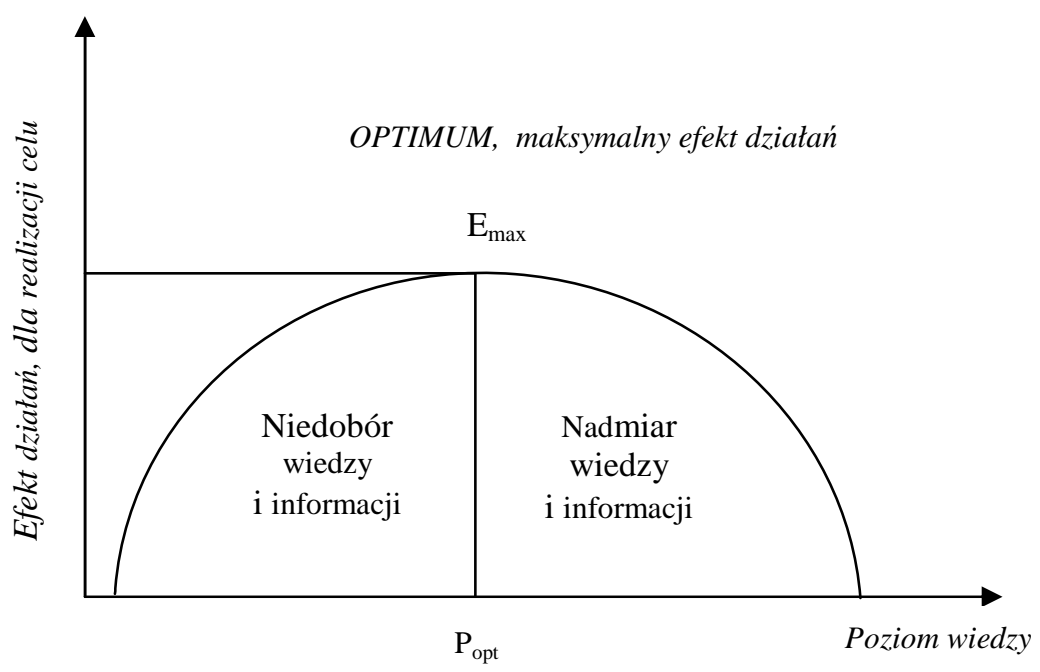

Rys. 1. Zasada optymalnej ilości informacji dla realizacji określonego działania w danej sytuacji

Źródło: opracowanie własne na podstawie: J. Wąchol, Systemy informatyczne $w$ zarzqdzaniu a pozyskiwanie wiedzy $w$ warunkach procesu globalizacji i integracji europejskiej, [w:] R. Borowiecki, M. Kwieciński (red.), Informacja w zintegrowanej Europie, Koncepcje i narzędzia zarzqdzania wobec wyzwań i zagrożeń, Difin, Warszawa 2006, s. 59.

${ }^{5}$ J. Ol eń s ki, Elementy ekonomiki informacji, Wydawnictwo UW, Warszawa 2000, s. 268.

${ }^{6} \mathrm{~L}$. Ki ełt y ka, W. Ję drzej c zy k, Komplementarne strategie rozwoju systemów informacyjnych przedsiębiorstw, [w:] R. B or ow i e k i, J. C ze kaj (red.), Zarzadzanie zasobami informacyjnymi w warunkach nowej gospodarki, Difin, Warszawa 2010, s. 70.

${ }^{7}$ M. Mielus, Informacyjny wymiar procesu decyzyjnego organizacji gospodarczej, [w:] R. B orow i e cki, J. Cze kaj (red.), Zarzadzanie zasobami informacyjnymi w warunkach nowej gospodarki, Difin, Warszawa 2010, s. 241. 
Określenie ilości potrzebnych informacji ma istotne znaczenie $\mathrm{w}$ procesie podejmowania decyzji. Podejmowanie decyzji na podstawie niewystarczających informacji jest z góry skazane na niepowodzenie. $Z$ drugiej strony, nadmiar informacji, zwłaszcza zbędnych, stanowi niepotrzebny ciężar, gdyż zajmuje uwagę i obniża skuteczność pracowników. Dla skutecznego podejmowania decyzji należy określić optimum ilości potrzebnych informacji, co graficznie prezentuje rys. 1 .

Wiedza, jako kluczowy czynnik rozwoju przedsiębiorstwa, przekłada się na sposób zarząazania informacją. Posiadanie właściwych informacji pozwala przedsiębiorcom na podejmowanie skutecznych decyzji, co daje szanse na kontynuowanie działalności przedsiębiorstw na rynku kapitałowym.

\section{BARIERY ZARZĄDZANIA INFORMACJĄ W EKSPLOATACJI OBIEKTÓW TECHNICZNYCH}

Właściwe zarządzanie informacją jest bardzo ważnym aspektem w procesie eksploatacji obiektów technicznych. Postrzeganie eksploatacji obiektów technicznych prezentowane jest przez J. Dietrycha. Pogląd autora przedstawia następujący cytat: „użytkowanie środków technicznych (maszyn, urządzeń, linii technologicznych itd.) jest elementem takiego ciągu działań, który J. Dietrych nazywa procesem zaspokajania potrzeb"8. Nazwa taka pochodzi od pierwszego składnika schematu zaspokajania potrzeb, jakim jest rozpoznanie potrzeby (RP) - rys. 2. Na podstawie identyfikacji potrzeby (PT) istnienia określonego artefaktu, rozumianego w tym wypadku jako obiektu technicznego, w otoczeniu człowieka (technosfera) w drugim etapie schematu następuje projektowanie (PR) nowego obiektu. W etapie trzecim opracowywana jest konstrukcja (KS) obiektu wraz z określeniem jego cech konstrukcyjnych i odpowiedniej dokumentacji. W kolejnym etapie dochodzi do wytwarzania (WT) potrzebnego obiektu w oparciu o zgromadzoną dokumentację. Wynikiem rozpoznanej potrzeby i ostatnim elementem schematu jest eksploatacja (EP), czyli użytkowanie nowego obiektu. Omówiony tok postępowania prezentuje rys. 2.

Na rys. 2 wskazano miejsce eksploatacji w strukturze procesu zaspokajania potrzeb oraz jej relacje z rozpoznaniem potrzeby. Do umiejętnego rozpoznawania potrzeb obiektów technicznych niezbędna jest umiejętność odczytywania informacji przesyłanych przez te obiekty. Odczytywanie informacji wysyłanych przez maszyny i urządzenia wymusza posiadanie i rozwijanie określonej wiedzy i umiejętności osób je obsługujących. Stąd potwierdza się, że zarządzanie informacją nierozerwalnie wiąże się z rozwojem wiedzy w przedsiębiorstwie. Zapre-

${ }^{8}$ J. Kaźmi erczak, Eksploatacja systemów technicznych dla studentów kierunków zarzqdzanie, Wydawnictwo Politechniki Śląskiej, Gliwice 2000, s. 7 [za:] J. Di et ry c h, System i konstrukcja, WNT, Warszawa 1978. 
zentowane zagadnienie stanowi podstawę do praktycznej tematyki związanej z zarządzaniem informacjami w procesach utrzymania ruchu.

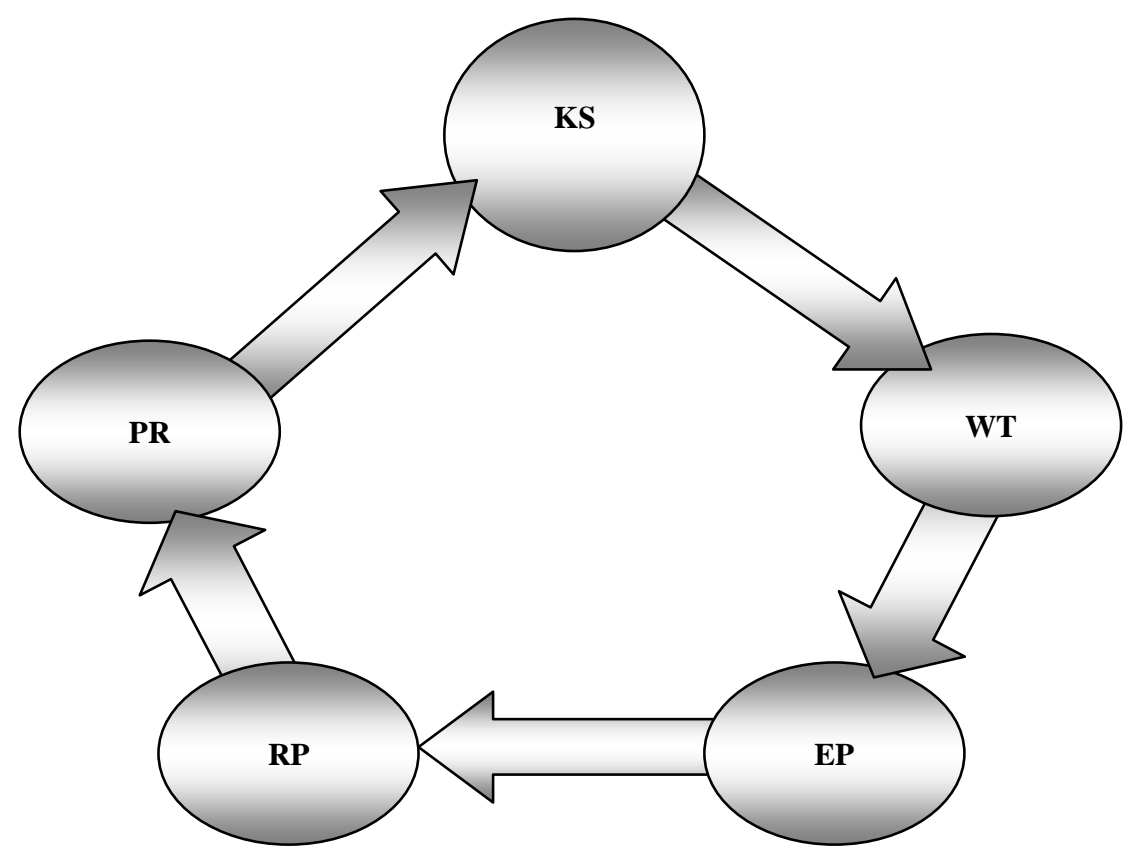

Rys. 2. Struktura procesu zaspokajania potrzeb w obszarze „technosfery” według J. Dietrycha

Źródło: J. K a źm i e r c z a k, Eksploatacja systemów technicznych dla studentów kierunków zarzadzanie, Wydawnictwo Politechniki Śląskiej, Gliwice 2000, s. 7 [za:] J. D i etry ch, System i konstrukcja, WNT, Warszawa 1978.

Działalność przedsiębiorstw na rynku kapitałowym wymusza implementację najnowocześniejszych rozwiązań usprawniających pracę ${ }^{9}$. Wykorzystywanie systemów komputerowych wspomagających działalność przedsiębiorstw stało się czynnością nieodzowną w codziennej pracy menedżerów ${ }^{10}$. Jednak zastosowanie najlepszych systemów nie zapewni ich całkowitej skuteczności bez zaangażowania człowieka. Nawet w perfekcyjnie zorganizowanych systemach wspomagających zarządzanie zdarzają się słabe ogniwa doprowadzające do zakłóceń $\mathrm{w}$ przepływie informacji w ramach funkcjonowania procesów utrzymania ruchu. Wynikiem takich zakłóceń są najczęściej awarie maszyn i urządzeń gene-

${ }^{9}$ Zob. T. Lis, Wyzwania organizacyjno-ekonomiczne $w$ organizacjach wdrażajacych rozwiazania informatyczne, „Organizacja i Zarządzanie”, Kwartalnik Naukowy nr 2(14), Wydawnictwo Politechniki Śląskiej, Gliwice 2011, s. 47-56.

${ }^{10}$ Zob. A. Puto, K. B rendzel-Skowera, Przeglad wybranych modeli rozwoju wspótczesnych przedsiębiorstw, ZN Zarządzanie nr 1, WZPCz, Częstochowa 2011, s. 80-91. 
rujące dodatkowe koszty. Skutki zakłóceń mogą też mieć inny charakter i objawiać się przede wszystkim w formie niezdatności maszyny lub urządzenia do użytkowania. Na podstawie zgromadzonej wiedzy z zakresu eksploatacji obiektów technicznych do przyczyn występowania zakłóceń w przepływie informacji zaliczyć można między innymi:

- niewystarczające przeszkolenie pracowników do pracy w dziale utrzymania ruchu,

- brak wyczerpujących źródeł informacji na temat stanu obiektu technicznego, rek,

- zbyt pochopnie wyciagane wnioski dotyczące przyczyn wystąpienia uste-

- nieprawidłową dokumentację techniczną,

- brak właściwej kontroli stanu obiektu,

- źle zaprojektowaną konstrukcję obiektu technicznego,

- niedostateczne zasoby ludzkie i finansowe do prowadzenia właściwego poziomu jakości systemu utrzymania ruchu,

- brak poszukiwania drobnych usterek ograniczających niezawodność obiektu,

- pogorszenie własności substancji smarujących i uszczelniających,

- niewłaściwy montaż maszyny lub urządzenia,

- niewłaściwe przeprowadzanie przeglądów i napraw maszyn,

- nieoptymalną organizację czasu potrzebnego do przeprowadzenia montażu, napraw, przeglądów,

- korzystanie z niewłaściwych systemów wspomagających utrzymanie ruchu,

- niewłaściwe wdrażanie systemów wspomagających utrzymanie ruchu,

- wadliwe materiały, z których wytworzony jest obiekt techniczny,

- brak szczegółowych charakterystyk trwałości elementów obiektów,

- negatywną zmianę własności mechanicznych tworzyw,

- trudności z lokalizacją uszkodzeń powstałych w obiekcie,

- niepoprawną eksploatację maszyn lub urządzeń,

- eksploatację obiektów nieprzyjazną dla ludzi i środowiska,

- występowanie nadmiernych obciążeń cieplnych maszyn i urządzeń,

- zużycie fizyczne obiektu technicznego.

$\mathrm{Na}$ podstawie analizy przedstawionych zakłóceń w przepływie informacji nasuwa się wniosek, iż wiedza pracownika ma decydujący wpływ na częstotliwość występowania awarii. Wiedza, doświadczenie i znajomość obsługi maszyn i urządzeń pozwalają na efektywne utrzymanie obiektów technicznych przedsiębiorstwa na rynku kapitałowym. 


\section{WYBRANE ASPEKTY ZARZĄDZANIA INFORMACJĄ W PRZEDSIĘBIORSTWACH PRZEMYSŁU CEMENTOWEGO}

System eksploatacji obiektów technicznych przedsiębiorstw przemysłu cementowego generuje wysokie koszty, które znajdują swoje odzwierciedlenie w kosztach produkcji. Stąd dążenie do obniżenia kosztów utrzymania ruchu jest jednym z priorytetowych celów przedsiębiorstw funkcjonujących na rynku kapitałowym. Dążenie do oszczędności napotyka różnego rodzaju przeszkody i bariery. Awarie obiektów technicznych, nieplanowane postoje ciągów technologicznych, większe koszty remontów to przykłady barier w zarządzaniu informacją. W wyniku działań $\mathrm{z}$ zakresu zarządzania informacją w procesach utrzymania ruchu przeprowadza się różne analizy mające na celu eliminację występujących problemów. W dalszej części pracy zostaną zaprezentowane analizy, które wskazują na występujące problemy i pokazuja, jakie decyzje podjęto w celu ich ograniczania. Pierwszym przykładem jest analiza kosztów remontów głównych przeprowadzanych raz do roku oraz kosztów awarii (rys. 3). Następnie, analizuje się stopień wykorzystania maszyn i urządzeń.

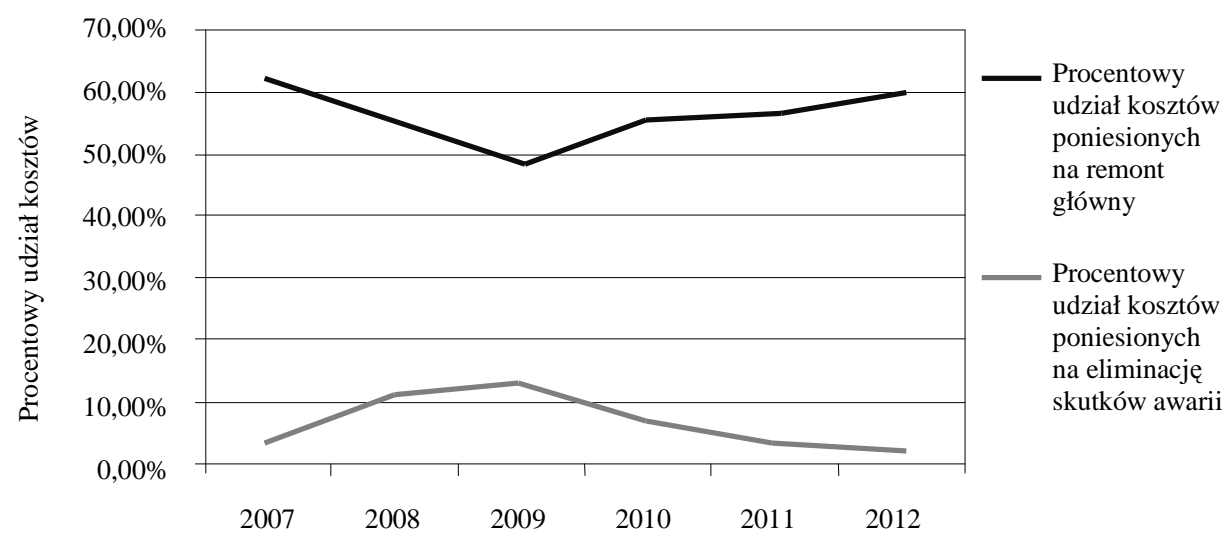

Poziom kosztów w badanych latach

Rys. 3. Relacja kosztów poniesionych na remont główny do kosztów poniesionych na usuwanie skutków awarii

Źródło: opracowanie własne.

$\mathrm{Na}$ rys. 3 zaprezentowano zależność występującą pomiędzy wielkością kosztów przeznaczonych na remonty główne ciagu technologicznego badanego zakładu w stosunku do kosztów związanych z występowaniem awarii na przestrzeni lat 2007-2012. Wykres prezentuje procentowy udział wymienionych 
wielkości w odniesieniu do budżetu utrzymania ruchu w każdym roku badanego okresu. Rok bazowy dla poniższych rozważań to rok 2007, w którym na remont główny parku maszynowego przeznaczono 58\% budżetu utrzymania ruchu, przy czym koszty awarii stanowiły jedynie 4\% budżetu. W 2008 r. nastapił spadek kosztów ponoszonych na remont główny, które stanowiły $45 \%$ budżetu, natomiast koszty awarii wzrosły i wynosiły prawie $11 \%$ budżetu. Najniższy poziom kosztów przeznaczonych na remont główny odnotowano w 2009 r. Było to zaledwie 36\% łącznego budżetu utrzymania ruchu w tym roku, przy jednocześnie najwyższym poziomie kosztów awarii, wynoszącym $12 \%$ ogólnych kosztów utrzymania ruchu. Rok 2010 przyniósł spadek kosztów awarii do poziomu 7\% i wzrost kosztów przeznaczonych na remonty główne do wielkości $49 \%$ budżetu utrzymania ruchu. Reakcja kadry kierowniczej na informacje dotyczące korelacji między wielkością kosztów remontów głównych, a awariami pociągnęła za sobą poprawny proces decyzyjny. $\mathrm{W}$ roku 2011 koszty utrzymania ruchu wynosiły $52 \%$ ogólnej wartości kosztów przeznaczonych w tym roku na utrzymanie ruchu. Na skutek takich decyzji koszty awarii w tym roku stanowiły jedynie 4\% kosztów utrzymania ruchu. Ostatni rok okresu badawczego zamyka się z wielkością prawie 58\% budżetu utrzymania ruchu przeznaczoną na remont główny, przy najniższym udziale kosztów awarii, stanowiącym nie wiele ponad $2 \%$ budżetu.

Na podstawie analizy danych przedstawionych na rys. 3 nasuwa się wniosek, iż wzrost występowania liczby awarii, a tym samym kosztów z nimi związanych, następuje na skutek ograniczenia budżetu przeznaczonego na realizację remontów głównych. Jednocześnie należy zauważyć, iż wraz ze wzrostem kosztów remontów głównych maleją koszty eliminacji awarii i jej skutków. Wynikiem narastającego ograniczenia zakresów remontów głównych, a tym samym ich kosztów, w 2008 i 2009 r. był narastający wzrost awaryjności parku maszynowego. Stąd podjęte decyzje w sprawie zwiększenia budżetu przeznaczonego na remont główny parku maszynowego przyniosły ograniczenie występowania awarii i ich skutków w 2010, 2011 i 2012 r. Analizując dane na rys. 3 nasuwa się wniosek, iż najniższy procentowy udział awarii w budżecie utrzymania ruchu uzyskuje się w sytuacji, kiedy na remonty główne przeznacza się ponad 50\% budżetu, tak jak w latach: 2007, 2011 i $2012^{11}$.

Następny analizowany wskaźnik to intensywne wykorzystanie maszyn i urządzeń, który liczony jest jako stosunek rzeczywistej wydajności maszyn i urządzeń do potencjalnej wydajności maszyn i urządzeń. W badanym przedsiębiorstwie przeanalizowano wskaźnik liczony na podstawie rzeczywistej wielkości produkcji głównych urządzeń $(\mathrm{X}, \mathrm{Y}, \mathrm{Z}) \mathrm{w}$ danym roku w stosunku do ich potencjalnej zdolności produkcyjnej w skali roku.

${ }^{11}$ Zob. S. Łęg o w i k-Ś w i ą c i k, Ocena uwarunkowań procesów kontroli w zakresie zarzqdzania zapasami w przedsiębiorstwach przemystu cementowego, ZN Zarzqdzanie $\mathrm{nr}$ 2, WZPCz, Częstochowa 2011, s. 110-112. 
Wynik wskaźnika Intensywnego wykorzystania maszyn i urządzeń badanego przedsiębiorstwa w latach 2008-2012

\begin{tabular}{|c|c|c|c|}
\hline $\begin{array}{c}\text { Intensywne wykorzystanie } \\
\text { maszyn i urządzeń }\end{array}$ & $\begin{array}{c}\text { Urządzenie } \\
\mathrm{X}\end{array}$ & $\begin{array}{c}\text { Urządzenie } \\
\mathrm{Y}\end{array}$ & $\begin{array}{c}\text { Urządzenie } \\
\mathrm{Z}\end{array}$ \\
\hline \hline 2008 & $87,07 \%$ & $86,89 \%$ & $93,12 \%$ \\
\hline 2009 & $58,29 \%$ & $88,41 \%$ & $87,16 \%$ \\
\hline 2010 & $60,85 \%$ & $19,27 \%$ & $83,28 \%$ \\
\hline 2011 & $11,13 \%$ & $68,21 \%$ & $80,56 \%$ \\
\hline 2012 & $15,39 \%$ & $86,16 \%$ & $75,70 \%$ \\
\hline Narastająco & $232,72 \%$ & $348,93 \%$ & $419,82 \%$ \\
\hline
\end{tabular}

Źródło: opracowanie własne.

Z przeprowadzonych obliczeń wynika, iż wykorzystanie zdolności produkcyjnych urządzenia $X \mathrm{w}$ analizowanym okresie istotnie obniżało się z $87 \%$ w 2008 r. do około $60 \%$ w latach 2009 i 2010 oraz $11 \%$ w 2011 r. i $15 \%$ w 2012 r. Jednocześnie sumaryczna wielkość wykorzystania zdolności produkcyjnych urządzenia $\mathrm{X} w$ analizowanym okresie jest najniższa spośród rozpatrywanych urządzeń.

Wykorzystanie zdolności produkcyjnych urządzenia $\mathrm{Y}$ w trzech spośród pięciu analizowanych lat osiągnęło podobny wynik, na poziomie około 86-89\%. W roku 2010 odnotowano najniższy dla tego urządzenia wskaźnik wykorzystania zdolności produkcyjnych wynoszący $19 \%$, który w roku następnym wynosił już 68\%. Wykorzystanie zdolności produkcyjnych urządzenia $\mathrm{Y}$ na przestrzeni lat 2008-2012 wykazało średni wynik i informuje o tym, że urządzenie wyprodukowało tyle klinkieru, jakby pracowało przez trzy i pół roku w ciagu pięcioletniego okresu badawczego.

Wykorzystanie zdolności produkcyjnych urządzenia $\mathrm{Z} w$ badanym okresie wykazało najlepszy wynik spośród trzech analizowanych urządzeń. Wynika stąd, iż urządzenie $\mathrm{Z}$ produkowało przez około 4,2 lat w ciągu pięcioletniego okresu badawczego. Wynik wskaźnika intensywnego wykorzystania urządzenia $\mathrm{Z}$ mieścił się w granicach od 76\% do 93\% zdolności produkcyjnych w badanym okresie.

\section{PODSUMOWANIE}

Przedsiębiorstwo na rynku kapitałowym spotyka się z różnymi problemami, barierami i ograniczeniami. Spośród występujących barier uwagę zwracają bariery w zarządzaniu informacją. Do sposobów eliminacji tych barier zalicza się 
rozwój, wiedzę i umiejętność odczytywania informacji przesyłanych przez obiekty techniczne. Podejmowanie decyzji dotyczących eksploatacji obiektów technicznych w przedsiębiorstwach przemysłu cementowego w oparciu o poprawne informacje pomaga uzyskać zaplanowany wynik oraz tworzyć konkurencyjne przedsiębiorstwo na rynku kapitałowym.

\section{BIBLIOGRAFIA}

Di etrych J., System i konstrukcja, WNT, Warszawa 1978.

Kaźmi erczak J., Eksploatacja systemów technicznych dla studentów kierunków zarzq̨dzanie, Wydawnictwo Politechniki Śląskiej, Gliwice 2000.

K i ł ł y k a L., J ę d r ze j c z y k W., Komplementarne strategie rozwoju systemów informacyjnych przedsiębiorstw, [w:] R. B or ow i e cki, J. C ze kaj (red.), Zarzqdzanie zasobami informacyjnymi w warunkach nowej gospodarki, Difin, Warszawa 2010.

Małku s T., Usprawnianie procesów informacyjnych $w$ systemie logistycznym przedsiębiorstwa, Zeszyty Naukowe nr 727 Akademii Ekonomicznej w Krakowie, Kraków 2007.

Mielu s M., Informacyjny wymiar procesu decyzyjnego organizacji gospodarczej, [w:] R. B orow i e ki, J. Czekaj (red.), Zarzadzanie zasobami informacyjnymi w warunkach nowej gospodarki, Difin, Warszawa 2010.

$\mathrm{Li}$ is T., Wyzwania organizacyjno-ekonomiczne $w$ organizacjach wdrażajacych rozwiazania informatyczne, „Organizacja i Zarządzanie”, Kwartalnik Naukowy, Wydawnictwo Politechniki Śląskiej, Gliwice 2011.

Łęg o wik-Ś wi ącik S., Ocena uwarunkowań procesów kontroli w zakresie zarzqdzania zapasami w przedsiębiorstwach przemystu cementowego, ZN Zarzqdzanie $\mathrm{nr} 2, \mathrm{WZPCz}$, Częstochowa 2011.

Now od ziń ski P., Misja wybranych spótek indeksu NewConnect Lead w kontekście ich wyborów strategicznych, ZN UE w Poznaniu nr 171, Poznań 2011.

O leńs ki J., Elementy ekonomiki informacji, Uniwersytet Warszawski, Warszawa 2000.

Puto A., Brendzel-Skowera K., Przeglad wybranych modeli rozwoju wspótczesnych przedsiębiorstw, ZN Zarzqdzanie nr 1, WZPCz, Częstochowa 2011.

Puto A. (red.), Teoretyczne i praktyczne aspekty funkcjonowania przedsiębiorstwa, WZPCz, Częstochowa 2012.

$\mathrm{W}$ ąc hol J., Systemy informatyczne $w$ zarzqdzaniu a pozyskiwanie wiedzy $w$ warunkach procesu globalizacji i integracji europejskiej, [w:] R. B orow i e cki, M. Kwi e cińs ki (red.), Informacja w zintegrowanej Europie, Koncepcje i narzędzia zarzqdzania wobec wyzwań $i$ zagrożeń, Difin, Warszawa 2006.

Zyg ał a R., Podstawy zarzqdzania informacja w przedsiębiorstwie, Wydawnictwo AE we Wrocławiu, Wrocław 2007. 
Helena Kościelniak,

Matgorzata Łęowik-Małolepsza

\section{THE BARRIERS IN INFORMATION MANAGEMENT IN CEMENT INDUSTRY ENTERPRISES}

The aim of this article is to present the role of information management in enterprises with underline the barriers in this process. The barriers can be limited by development, knowledge and skills for information understanding. Moreover, there is presented the information as necessity of making a decision process. In last part of the article the problems in barriers in information management were presented on the example of cement industry enterprises.

Key words: information management, making a decision, development, enterprises. 